Курпе О. Г. Кухар B. B. Присяжний А. Г.

\title{
УДОСКОНАЛЕННЯ ТА АПРОБАЦІЯ МЕТОДОЛОГІЇ КЕРУВАННЯ ЯКІСТЮ ЛИСТОВОГО МЕТАЛОПРОКАТУ
}

Якість продукції - це сукупність властивостей, які обумовлюють ії придатність задовольнити певні потреби відповідно до призначення [1]. Для повноцінного функціонування та досягнення розвитку підприємства/компанії система якості продукції повинна бути впроваджена на всіх процесних ділянках, починаючі від постачання сировини і закінчуючи процесами роботи зі споживачами продукції (Клієнтами) [1]. Аналіз роботи вітчизняних підприємств показав, що система якості на них функціонує тільки у сфері технології, а використання цієї системи в інших сферах, що взаємодіють 3 технологією, є формальним. Тому подальше вдосконалення підходів до превентивного керування якістю продукції та їх системне використання на всіх процесних ділянках виробництва $\epsilon$ актуальною проблемою.

Аналіз даних, опублікованих у роботах $[2,3]$, дозволив зробити виносок про те, що для вирішення зазначеної проблеми ефективне поєднання системи якості ISO 9001 з інструментами системи ощадливого виробництва Lean, що є системою організації і управління розробленням продукції, виробництвом, взаємовідношеннями 3 постачальниками і споживачами, коли продукція виготовляється у точній відповідності із запитами споживачів і з меншими втратами. Зокрема, одним з підходів, який передбачений системою якості ISO $9001[4,5]$ та може бути використаний для розв'язання проблеми, що розглядається, є використання «Ризик-орієнтованого мислення». Сутність його полягає в тому, що та чи інша організація повинна виконати оцінку ризиків, тобто визначити чинники, які можуть спричиняти відхилення іï процесів та системи управління якістю від запланованих результатів, та розробити дії стосовно ризиків для запобігання небажаним ефектам, грунтуючись на наявних даних про вироблену продукцію й показники її якості. При цьому, необхідно планувати, у який спосіб інтегрувати та запроваджувати дії до процесів системи управління якістю організації та оцінювати їх результативність, тобто повинен працювати цикл Деминга, або цикл PDCA плануй (Plan), роби (Do), перевіряй (Check), впливай (Act).

Серед інструментів системи ощадливого виробництва Lean, які доцільно використовувати в поєднанні з системою якості ISO 9001, можна відзначити: а) бенчмаркінг, що полягає у порівнянні показників, результатів, параметрів якості тощо з аналогічними виробництвами, виробниками з метою пошуку найкращого досвіду [6]; б) діаграму Ішикави - графічний спосіб дослідження та визначення найбільш суттєвих причинно-наслідкових взаємозв'язків між чинниками та наслідками у проблемі, що досліджується [7]; в) принцип Парето емпіричне правило, згідно з яким для багатьох явищ 80 \% наслідків спричинені 20 \% відсотками причин [7]. Разом із тим аналіз досвіду роботи металургійних підприємств України, які виробляють листовий металопрокат, показав, що на них недостатньо повно використовується методологія, яка б грунтувалась на поєднанні систем якості ISO та ощадливого виробництва Lean, що утруднює вдосконалення технології та покращення якості продукції.

Метою роботи є забезпечення необхідних показників якості листової металопродукції (на прикладі товстолистового прокату) на основі поєднання принципів систем ISO та Lean.

Для досягнення поставленої мети були сформульовані та вирішені наступні задачі:

- вдосконалити методологію оптимізації технології та покращення якості прокату;

- виконати оцінку ефективності даної методології для забезпечення необхідних показників фізико-механічних властивостей товстолистового прокату зі сталі марки К60.

Вдосконалена в роботі методологія керування якістю прокату грунтується на використанні циклу Деминга (цикл РDCA) та включає (рис. 1) встановлення, визначення значень те- 
хнологічних параметрів, які впливають на якість продукції, їх контроль, накопичення, обробку та механізми покращення. Запропонована методологія застосовується для продукції, яка пройшла стадію засвоєння та виробляється в промислових об'ємах, а також може бути використана компаніями-партнерами, що займаються наданням продукції підприємствавиробника додаткової доданої вартості (наприклад, додаткова обробка поверхні прокату).

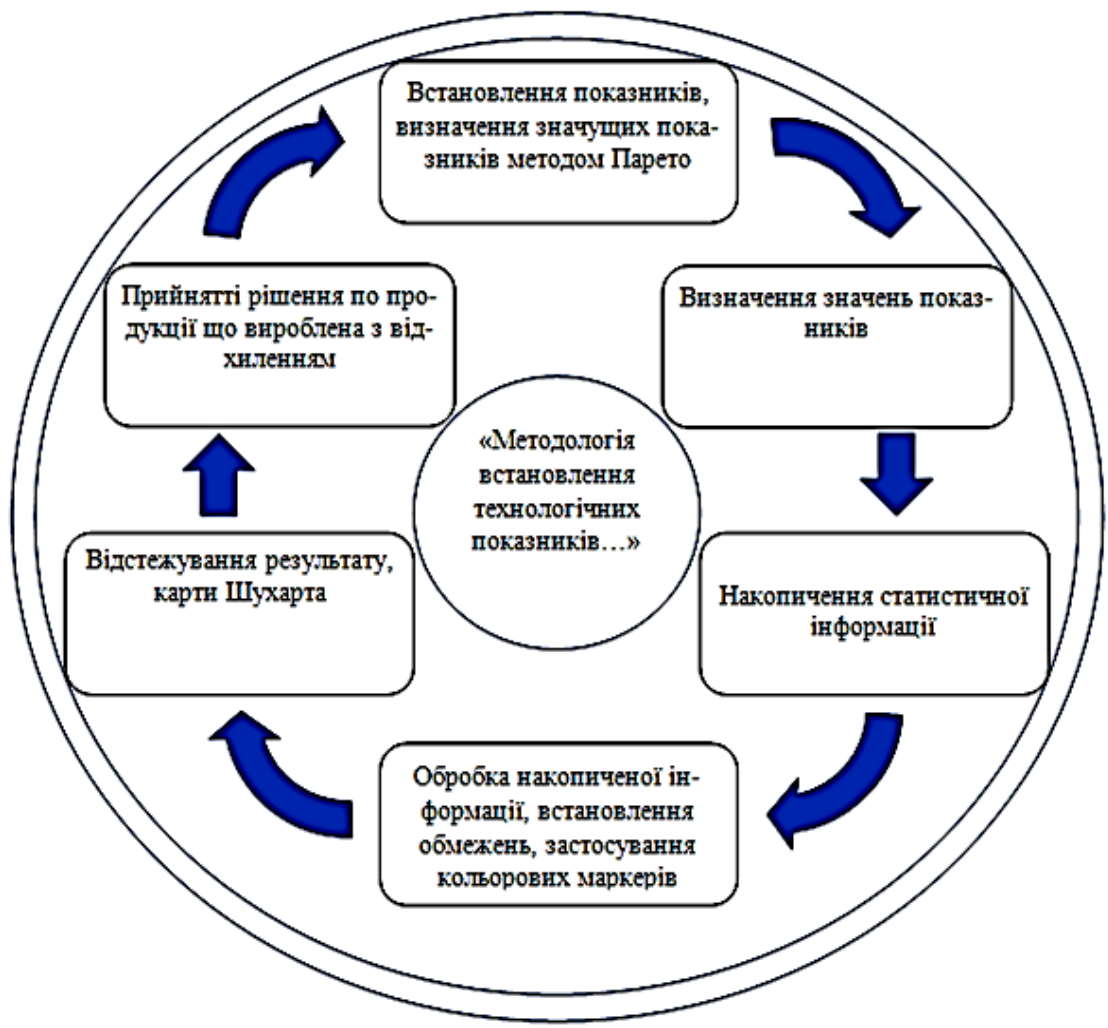

Рис. 1. Відображення методології керування якістю прокату в циклі PDCA

Для здійснення контролю процесу виробництва та забезпечення якості листового прокату необхідно встановлення та керування відповідними технологічними параметрами. Їх можна встановити за допомогою діаграми Ішикави [7], а також на основі технологічних інструкцій, документації або літературних даних, опублікованих, наприклад, в роботі [8]. При цьому, встановлення технологічних параметрів може бути загалом для комплексу показників якості або для окремих показників (чи груп показників) якості. Також для первинного встановлення параметрів технології може бути використано результати бенчмаркінгу для аналогічних виробництв, якщо такі дані є відкритими.

Перелік технологічних параметрів може бути нескінченно великим, тому, у деяких випадках, необхідно контролювати тільки найбільш значущі з них. Значущі показники, які впливають на якість прокату, можна визначити, наприклад, за допомогою методу Парето [7].

Після встановлення переліку технологічних параметрів необхідно визначити їх значення, які можуть встановлюватись на підставі аналізу виробництва аналогічної продукції, статистичної обробки наявної інформації, наукових досліджень, по літературних джерелах (наприклад, по даних роботи [8]) та іншими можливими способами.

Для оптимізації технології та підвищення якості прокату необхідне накопичення статистичної інформації та її обробка. Для отримання статистичних даних при виробництві прокату необхідно контролювати значення всіх встановлених технологічних параметрів та зберігати цю інформацію. Зазначені параметри слід об’єднувати 3 показниками якості продукції за допомогою системи простежування, яка $є$ обов'язковою для сучасного виробництва.

Обробка накопиченої статистичної інформації здійснюється на основі багатофакторного аналізу. Кожен з показників якості прокату повинен аналізуватися окремо або в групі 
3 показниками аналогічного рівня (наприклад, в групу можуть бути об'єднані показники фізико-механічних властивостей металу). Першим кроком аналізу отриманих статистичних даних $\epsilon$ побудова діаграм розподілу по кожному з показників якості прокату з встановленням, в залежності від процесу, обмежень у відповідності до Правила $3 \sigma$ або 6б [9]. Встановлені обмеження повинні відповідати наявним нормативним документам або бути більш жорсткими. На другому кроці обробки накопиченої статистичної інформації для кожного з встановлених технологічних параметрів, які впливають на даний показник якості прокату, необхідно побудувати діаграми розподілу та встановити обмеження, які забезпечують отримання продукції необхідної якості. При цьому слід уникати окремого встановлення обмежень для взаємозалежних технологічних параметрів, а також встановлення різних обмежень для одного й того ж технологічного параметра, який впливає на різні показники якості прокату. Для визначення обмежень технологічних параметрів доцільно використовувати статистичні моделі, які можна побудувати на підставі обробки отриманих масивів даних за допомогою, наприклад, засобів Statistica або Microsoft Excel [10].

Для візуальної оцінки стану й визначення рівнів технологічного процесу при встановленні обмежень технологічних параметрів рекомендується застосовувати кольорові маркери. Зокрема, червоний маркер можна встановлювати, коли технологічний параметр відхиляється від меж, які забезпечують отримання даного показника якості прокату у відповідності зі стандартом (це відповідає порушенню технологічного процесу). Жовтий маркер можливо застосовувати, коли технологічний параметр відхиляється від меж, які забезпечують підвищені вимоги, встановлені в межах керування системою якості; при цьому даний показник якості прокату ще знаходиться у межах відповідності стандарту (це означає, що технологічний процес потребує уваги). Зелений маркер слід використовувати, коли технологічний параметр відповідає межам встановлених (підвищених) вимог до якості прокату; при цьому технологічний процес є стабільним. Використання цього підходу в межах поєднання систем ISO та Lean дає можливість не тільки стабілізувати технологічний процес та підвищити якість продукції, але й знизити виробничі витрати шляхом застосування обмежень в отриманні надвисоких рівнів показників якості. Наприклад, стабільне отримання на середньому рівні вимог показників фізико-механічних властивостей товстолистового прокату для магістральних трубопроводів дозволяє економити мікролегуючі елементи при виплавці сталі.

Для відстеження результату та контролю за дотриманням встановлених обмежень по технологічних параметрах можуть бути використані безпосередній контроль співробітником відділу контролю якості на місці фіксації технологічного параметра, системи візуалізації (контролю) технологічних параметрів або автоматична система контролю технологічного процесу. Також широко застосовуються контрольні карти Шухарта, які являють собою графіки зміни параметрів вибірки: зазвичай середнього значення і стандартного відхилу, який розраховується в процесі накопичування даних $[7,11]$. У разі невідповідності допустимому рівню відхилення технологічним персоналом приймаються рішення щодо забезпечення входження даного технологічного параметра у необхідні межі.

Рішення щодо продукції, яка отримана $з$ відхиленнями, приймаються відповідно до вимог ISO 9001 [4, 5]. Так, продукція, що виробляється партією, для кожної одиниці якої всі показники знаходяться в межах зеленого маркеру, вважається відповідною. Якщо по окремих одиницях партії є показники, які знаходяться в межах жовтого маркеру, то призначається додатковий контроль якості для зазначених одиниць продукції. Продукція 3 жовтими маркерами вважається відповідною тільки після підтвердження по результатах додаткового контролю. У випадку, коли для окремих одиниць партії $є$ показники, що знаходяться в межах червоного маркеру, продукція, якщо це не узгоджено із Замовником, вважається невідповідною та переводиться в нижчу якість або в брак. Партія прокату може містити набір одиниць продукції з комбінацією будь яких маркерів, якщо це узгоджено із Замовником, або відокремлюватися в рівні партії відповідно до маркерів.

Нижче виконана оцінка ефективності запропонованої Методології для встановлення поточного рівня якості та напрямків покращення таких показників якості, як границя текучо- 
сті $\sigma_{\mathrm{T}}$, тимчасовий опір $\sigma_{\text {в }}$ та відносне подовження $\delta$, при виробництві товстолистового прокату зі сталі марки К60 товщиною 14 мм, що вироблявся по режимах термомеханічної прокатки 3 прискореним охолодженням на стані 3600 «МК «АЗОВСТАЛЬ» (м. Маріуполь).

Перелік технологічних параметрів, які впливають на рівень зазначених показників якості прокату, визначений по практичних даних та з роботи [8]. Цей перелік включає хімічний склад сталі з такими елементами, які впливають на механічні характеристики металу $(\mathrm{C}, \mathrm{Mn}, \mathrm{Nb}, \mathrm{V}, \mathrm{Mo}, \mathrm{Cr}, \mathrm{Ni}, \mathrm{Cu})$, а також температуру початку прокатки в чорновій кліті (ТППч), температуру початку другої стадії прокатки в чорновій кліті, яка обумовлена початком гальмування рекристалізації (ТГР), температуру початку та закінчення прокатки в чистовій кліті (ТПП, ТЗП), температуру металу на початку та закінченні установки контрольованого охолодження (ТПО, ТЗО).

Для визначення технологічних параметрів, які впливають на показники якості, що досліджувались, були побудовані діаграми Парето по кожному показнику. Підставою для побудови діаграм Парето $\epsilon$ величина вірогідності апроксимації $R^{2}$ та величина коефіцієнта кореляції Пірсона (за модулем), які були отримані при визначенні залежності між кожним показником якості та технологічним параметром на основі робіт $[9,10]$. На рис. 2, в якості прикладу, представлені діаграми Парето, побудовані для границі текучості $\sigma_{\mathrm{T}}$. Для масиву даних, що використовувався в розрахунках, критичне значення коефіцієнта кореляції Пірсона становить 0,17 для рівня значимості $\mathrm{p}=0,05$ (див. рис. 2, б). Технологічні параметри, коефіцієнт кореляції Пірсона яких до відповідного показника якості прокату є меншим за 0,17, не є значимими. У табл. 1 наведені технологічні параметри, які по результатах статистичної обробки даних $є$ значимими. Дії щодо вдосконалення технології та підвищення якості прокату розроблялись тільки для значимих технологічних параметрів, а незначимі параметри були залишені на рівні, який наразі встановлено технологічним процесом.

Таблиця 1

Параметри, які є значимими при визначенні відповідного показника якості прокату

\begin{tabular}{|c|c|c|c|}
\hline \multirow{2}{*}{ Технологічний параметр } & \multicolumn{3}{|c|}{ Значення кореляції Пірсона за показниками } \\
& \multicolumn{3}{|c|}{ якості прокату } \\
\cline { 2 - 4 } & $\sigma_{\mathrm{T}}$ & $\sigma_{\mathrm{B}}$ & $\delta$ \\
\hline $\mathrm{TГP}$ & 0,316 & 0,379 & - \\
\hline $\mathrm{V}$ & 0,236 & 0,252 & - \\
\hline $\mathrm{TПO}$ & $-0,224$ & $-0,334$ & - \\
\hline $\mathrm{Ni}$ & $-0,213$ & $-0,219$ & - \\
\hline $\mathrm{Mo}$ & $-0,196$ & - & - \\
\hline $\mathrm{Cu}$ & $-0,188$ & $-0,202$ & - \\
\hline $\mathrm{C}$ & 0,178 & 0,246 & - \\
\hline $\mathrm{T} 3 \mathrm{O}$ & - & $-0,241$ & 0,412 \\
\hline
\end{tabular}

У відповідності до запропонованої методології керування якістю прокату були також побудовані діаграми розподілу по зазначених показниках якості товстих листів. На рис. 3 в якості прикладу представлений розподіл границі текучості прокату. Аналіз побудованих діаграм дозволив встановити, що розподіл границі текучості має випадки отримання нижчого за нормативний рівень та граничного 3 мінімальним нормативним рівнем вимог. По відношенню до розподілу тимчасового опору також є випадки отримання нижчого за нормативний рівень вимог. Розподіл відносного подовження має суттєву кількість випадків отримання нижчого за нормативний рівень вимог, що свідчить про нестабільність технологічного процесу щодо отримання даного показника якості листового металопрокату. 


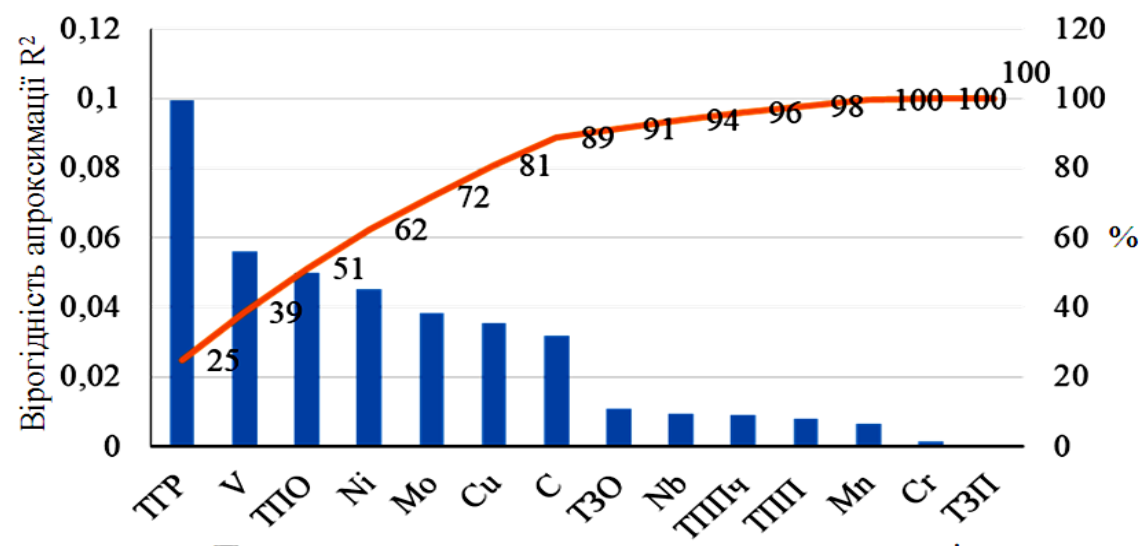

Параметри, шо впливають на границю текучості

a

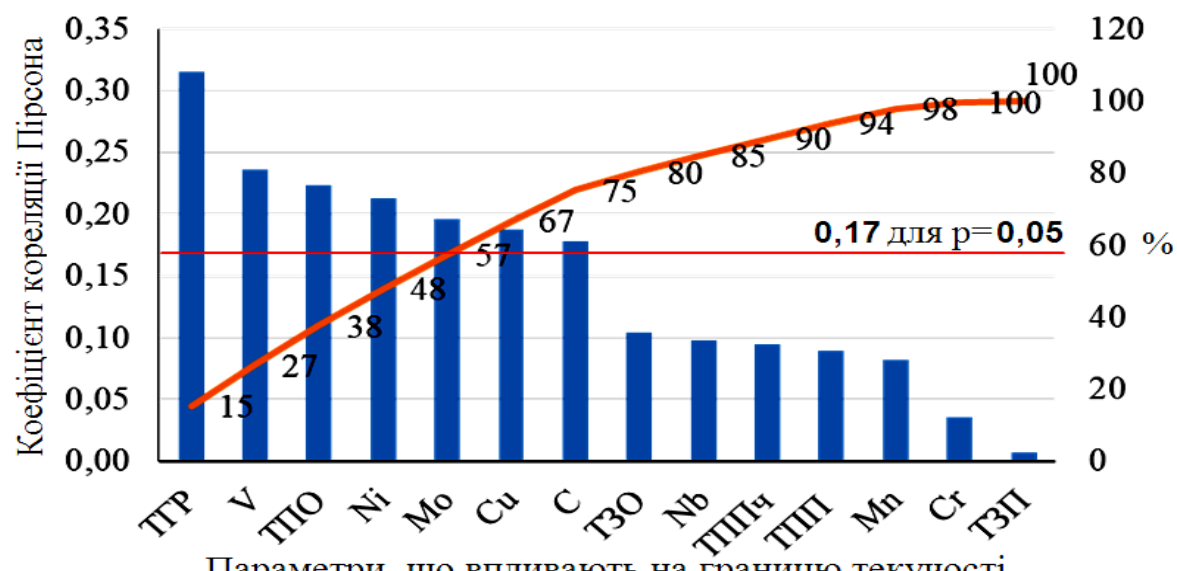

Параметри, що впливають на границю текучості

6

Рис. 2. Діаграма розподілу вірогідності апроксимації (а) та коефіцієнта кореляції Пірсона (б) по параметрах, які впливають на границю текучості прокату зі сталі К60

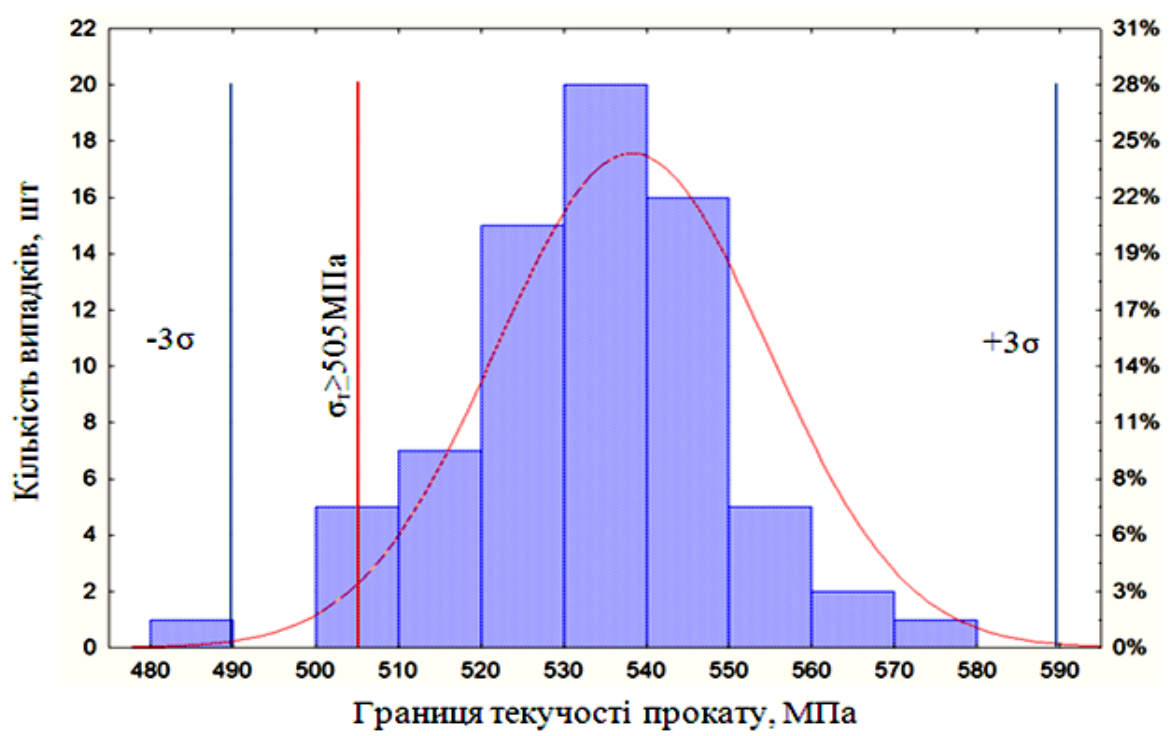

\begin{tabular}{|l|l|l|}
\hline Норматнвні параметри & & $\sigma_{\mathrm{\tau}} \geq 505 \mathrm{MПа}$ \\
\hline \multirow{2}{*}{ Статнстнчні параметри: } & & середнє значення 537,99 МПа \\
\cline { 3 - 3 } & & стандартне відхилення 16,35 МПа \\
\hline Розраховані параметри & & $3 \sigma=489-587 \mathrm{MПа}$ \\
\hline
\end{tabular}

Рис. 3. Початковий розподіл границі текучості прокату товщиною 14 мм зі сталі К60 
Для стабілізації технології прокатки та підвищення якості прокату по показниках, що досліджувались, були встановлені обмеження та за допомогою кольорових маркерів визначені рівні процесу, представлені в табл. 2.

Таблиця 2

Встановлені обмеження показників якості прокату та рівні технологічного процесу

\begin{tabular}{|c|c|c|c|c|c|}
\hline \multirow{2}{*}{ Показник якості } & \multicolumn{5}{|c|}{ Рівні процесу } \\
\cline { 1 - 6 } & $\begin{array}{c}\text { порушення } \\
\text { процесу }\end{array}$ & $\begin{array}{c}\text { потребує } \\
\text { уваги }\end{array}$ & стабільний & $\begin{array}{c}\text { потребує } \\
\text { уваги }\end{array}$ & $\begin{array}{c}\text { порушення } \\
\text { процесу }\end{array}$ \\
\hline Границя текучості, МПа & $<505$ & $505-510$ & $511-570$ & $571-580$ & - \\
\hline Тимчасовий опір, МПа & $<590$ & $590-600$ & $600-660$ & $661-710$ & $>710$ \\
\hline Відносне подовження, \% & $<22$ & $22,0-22,5$ & $22,5-25,0$ & $25,0-26,0$ & - \\
\hline
\end{tabular}

Для отримання необхідного рівня параметрів технології по встановлених обмеженнях показників якості прокату в масиві даних, що досліджувався, за допомогою фільтрів залишали тільки ті дані, які відповідають стабільному рівню процесу (позначений зеленим маркером у табл. 3), та встановлювали їх межі. Фільтрацію починали з найбільш нестабільного показника якості, яким у даному випадку є відносне подовження. При цьому перелік значимих технологічних параметрів для всіх трьох показників якості листів був однаковий. При встановленні жовтого та червоного маркерів та відповідних до них рівнів технологічного процесу враховували значення кореляції Пірсона по показниках якості прокату (див. табл. 1). Визначення меж порушення технології прокатки (позначені червоним маркером у табл. 3) здійснювали по даним, які відповідають межам нормативних вимог до показників якості товстолистового металопрокату.

Таблиця 3

Встановлені обмеження технологічних параметрів та показників якості прокату

\begin{tabular}{|c|c|c|c|c|c|}
\hline \multirow[b]{2}{*}{$\begin{array}{c}\text { Показник якості/ } \\
\text { технологічний параметр }\end{array}$} & \multicolumn{5}{|c|}{ Рівні процесу } \\
\hline & $\begin{array}{c}\text { порушення } \\
\text { процесу }\end{array}$ & $\begin{array}{c}\text { потребує } \\
\text { уваги }\end{array}$ & стабільний & $\begin{array}{c}\text { потребує } \\
\text { уваги }\end{array}$ & $\begin{array}{c}\text { порушення } \\
\text { процесу }\end{array}$ \\
\hline Границя текучості, МПа & $<505$ & $505-510$ & $511-570$ & $571-580$ & \\
\hline Тимчасовий опір, МПа & $<590$ & $590-600$ & $600-660$ & $661-710$ & $>710$ \\
\hline Відносне подовження, \% & $<22$ & $22,0-22,4$ & $22,5-25,0$ & $25,1-26,0$ & \\
\hline ТГР,${ }^{\circ} \mathrm{C}$ & $<876$ & $876-908$ & $909-1008$ & - & $>1008$ \\
\hline $\mathrm{V}, \%$ & $<0,055$ & $\begin{array}{c}0,056- \\
0,059\end{array}$ & $0,06-0,08$ & - & $>0,08$ \\
\hline $\mathrm{T \Pi O},{ }^{\circ} \mathrm{C}$ & $<717$ & $718-720$ & $721-737$ & - & $>737$ \\
\hline $\mathrm{Ni}, \%$ & - & - & $0-0,29$ & - & $>0,29$ \\
\hline Mo, $\%$ & - & - & $0-0,07$ & - & $>0,07$ \\
\hline $\mathrm{Cu}, \%$ & - & - & $0-0,28$ & - & $>0,28$ \\
\hline $\mathrm{C}, \%$ & - & - & $0,08-0,11$ & - & $>0,11$ \\
\hline $\mathrm{T} 3 \mathrm{O},{ }^{\circ} \mathrm{C}$ & $<541$ & $542-595$ & $596-640$ & - & $>640$ \\
\hline
\end{tabular}

Слід зазначити, що важливу роль при використанні запропонованої методології для встановлення рівнів технологічного процесу відіграє якість первинно розробленої (базової) технології. У випадку, що аналізується, був розроблений помилковий базовий технологічний процес термомеханічної прокатки товстих листів, який не дозволив отримати необхідні показники фізико-механічних властивостей прокату за допомогою прискореного охолодження, 
що видно по негативних кореляціях параметрів охолодження. Потрібний рівень властивостей товстих листів досягався здебільшого за допомогою параметрів процесу прокатки.

Після встановлення рівнів технологічних параметрів (див. табл. 3), необхідних для отримання стабільних показників якості товстолистового металопрокату, були побудовані діаграми розподілу границі текучості, тимчасового опору та відносного подовження металу. На рис. 4 в якості прикладу представлена діаграма розподілу границі текучості прокату товщиною 14 мм зі сталі марки К60 для зеленого рівня технологічного процесу.

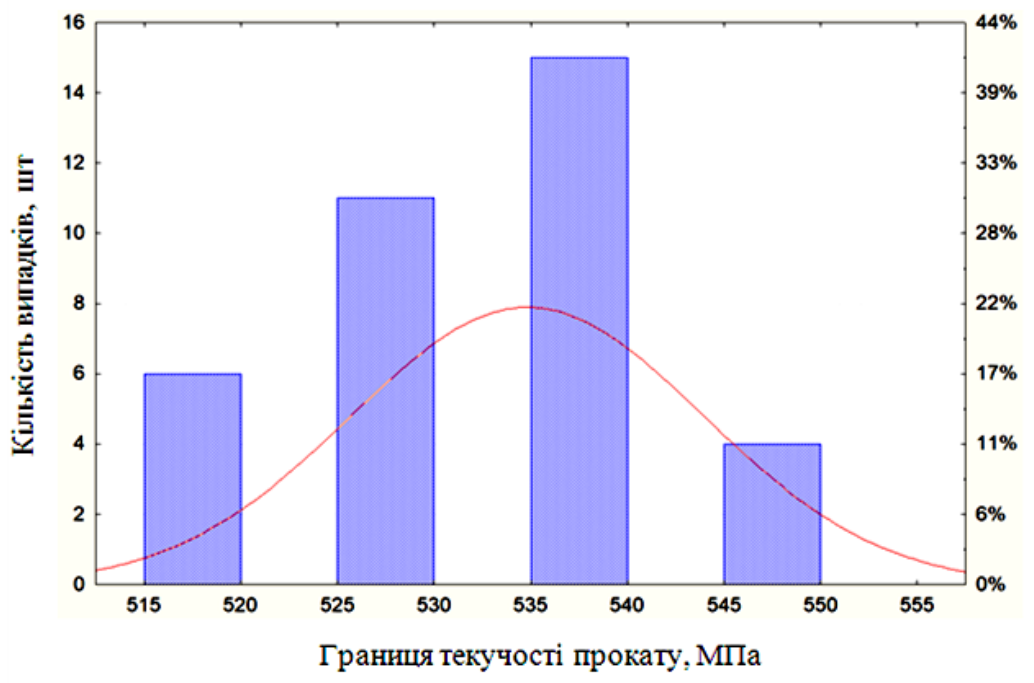

\begin{tabular}{|l|l|l|}
\hline Нормативні параметри & & $\sigma_{\mathrm{\tau}} \geq 505 \mathrm{MПа}$ \\
\hline \multirow{2}{*}{ Статистичні параметри: } & & середнє значення 534,72 МПа \\
\cline { 3 - 3 } & & стандартне відхилення 9,10 МПа \\
\hline Розраховані параметри & & $3 \sigma=507-562 \mathrm{MПа}$ \\
\hline
\end{tabular}

Рис. 4. Розподіл границі текучості прокату товщиною 14 мм зі сталі марки К60 для зеленого рівня технологічного процесу

Аналіз отриманих результатів показав, що зелений рівень технологічного процесу забезпечує отримання показників фізико-механічних властивостей товстолистового прокату у межах нормативних вимог. При цьому зменшилося стандартне відхилення по границі текучості, тимчасовому опору та відносному подовженню прокату на 44 \%, 31 \% та 46 \% відповідно, що свідчіть про підвищення стабільності технології.

\section{ВИСНОВКИ}

Вдосконалена методологія керування якістю продукції та виконана оцінка ефективності її застосування стосовно до умов отримання товстолистового прокату товщиною 14 мм та вище зі сталі категорії міцності К60. Результати цієї оцінки показали, що запропонована Методологія дозволяє забезпечити отримання показників фізико-механічних властивостей товстих листів відповідно до вимог, встановлених нормативними документами, а також керувати рівнем даних показників для отримання економічного ефекту в межах поєднання систем ISO та Lean.

\section{СПИСОК ВИКОРИСТАНОЇ ЛІТЕРАТУРИ}

1. Минаев А. А., Смирнов А. Н., Лейрих И. В. Металлопродукция: сертификация, маркировка, упаковка: учеб. пособие. Донецк: Норд-Пресс, 2006. 291 с.

2. Синго С. Изучение производственной системы Тойоты с точки зрения организации производства. Москва: Институт комплексных стратегических исследований, 2010. 312 с.

3. Оно Т. Производственная система Тойоты. Уходя от массового производства. Москва: Институт комплексных стратегических исследований, 2013. 208 с.

4. ДСТУ ISO 9000:2015. (ISO 9001:2015, IDT).Системи управління якістю. Основні положення та словник термінів. 2016. 
5. ДСТУ ISO 9001:2015. (ISO 9001:2015, IDT). Системи управління якістю. Вимоги. 2016.

6. Воробйова Н. П. Бенчмаркінг як інструмент підвищення конкурентоспроможності організації. Проблеми інноваційно-інвестиційного розвитку. 2018. 14. С. 13-20.

7. Найзабеков А. Б., Талмазан В. А., Шмидт Н. Ю. Квалиметрия в обработке металлов давлением: учеб. пособие. Алматы: РИК по УиМЛ, 2005. 134 с.

8. Остапенко А. Л. Производство проката: учеб.-справ. пособие в 3 т. Т. 3. кн. 1: Информационное и методическое обеспечение проектирования технологии и оборудования листовых и полосовых станов горячей прокатки. Москва: Теплотехник, 2007. 344 с.

9. Кобзарь А. И. Прикладная математическая статистика. Для инженеров и научных работников. Москва: ФИЗМАТЛИТ, 2006. 816 с.

10. Вуколов Э. А. Основы статистического анализа. Практикум по статистическим методам и исследованию операций с использованием пакетов STATISTICA и EXCEL: учеб. пособие. 2-е изд., испр. и доп. Москва: ФОРУМ, 2008. 464 с.

11. ДСТУ ISO 8258-2001. (ISO 8258:1991, IDT). Статистичний контроль. Контрольні карти Шухарта. 2003.

\section{REFERENCES}

1. Minaev A.A., Smirnov A.N., Leirikh I.V. Metal products: certification, marking, packaging: textbook. allowance. Donetsk: Nord-Press. 2006. 291 p. (in Russian).

2. Shingo S. Study of the Toyota production system from the point of view of production organization. Moscow: Institute for Comprehensive Strategic Studies. 2010. 312 p. (in Russian).

3. Ono T. Toyota Production System. Moving away from mass production. Moscow: Institute for Complex Strategic Studies. 2013. 208 p. (in Russian).

4. DSTU ISO 9000: 2015. (ISO 9001: 2015, IDT). Quality management systems. The main provisions and vocabulary of terms. 2016. (in Ukrainian). Ukrainian).

5. DSTU ISO 9001: 2015. (ISO 9001: 2015, IDT). Quality management systems. Requirements. 2016. (in

6. Vorobyova N.P. Benchmarking as an instrument for advancing the competitiveness of organization. Problems of innovation and investment development. 2018. 14, pp. 13-20. (in Ukrainian).

7. Nayzabekov A.B., Talmazan V.A., Schmidt N.Yu. Qualimetry in the processing of metals by pressure: textbook. allowance. Almaty: RIK on UiML, 2005. 134 p. (in Russian).

8. Ostapenko A.L. Production of rental: textbook. manual in 3 volumes: 3. 1: Informational and methodological support for the design of technology and equipment for sheet and strip hot rolling mills. Moscow: Teplotekhnik. 2007. 344 p. (in Russian).

9. Kobzar A.I. Applied Mathematical Statistics. For engineers and scientists. Moscow: FIZMATLIT, 2006. 816 p. (in Russian).

10. Vukolov E.A. Fundamentals of statistical analysis. Practical work on statistical methods and operation research using the STATISTICA and EXCEL packages: textbook. allowance. 2nd ed., Rev. and add. Moscow: FORUM, 2008. 464 p. (in Russian).

11. DSTU ISO 8258- 2001. (ISO 8258: 1991, IDT). Statistical control. Shewharts control picture. 2003. (in Ukrainian).

Курпе О. Г. - канд. техн. наук, гол. експерт ТОВ «МЕТІНВЕСТ ХОЛДІНГ»; E-mail: aleksandr.kurpe@gmail.com; https://orcid.org/0000-0003-2039-7239

Кухар В. В. $\quad$ - д-р. техн. наук, проф. ДВНЗ «ПДТУ»;

E-mail: kvv.mariupol@gmail.com ; https://orcid.org/0000-0002-4863-7233

Присяжний А. Г. - канд. техн. наук, доц. ДВНЗ «ПДТУ»;

E-mail: agp87514@gmail.com; http://orcid.org/0000-0001-8062-075X

ТОВ «МЕТІНВЕСТ ХОЛДІНГ» - Товариство 3 обмеженою відповідальністю «МЕТІНВЕСТ ХОЛДІНГ», м. Маріуполь;

ДВНЗ «ПДТУ» - Державний вищий навчальний заклад «Приазовський державний технічний університет», м. Маріуполь. 